\title{
SUNN PEST SPECIES AND ITS HIBER NATION SITES IN DIYALA GOVERNORATE / IRAQ
}

\section{M .Shblawy}

Researcher

Office of Diyala Agriculture Depa. of plant protection

Ministry of Agriculture

\section{ABSTRACT}

This study was conducted in Diyala governorate/Iraq during wintering period of the sunn pest from Dece. 2016 to Feb. 2017. Three species of sunn pest was diagnostic. These species are Eurygaster integriceps (Puoton, 1881), E. testudinaria (Geoffory, 1785) and $E$.maura (len.1758).E .maura was new species recorded to Iraq funna .E. integriceps is The most abundance of the three species hibernated in the fields of the four region of Diyala governorate. The results showed that the three species of genus Eurygaster which diagnostic in Diyala governorate were overwintered as an adults under bushes, dead leaves, weed ,date palm leaf base .The heights total number of adults $(68,56,51$ and 44adults/5m2) was found under cogon grass(Imperata cylindrican L.), Bermuda grass(Cyndo dactylon L.),Grape tree(Vitis vinifera L.)and Eucalyptus tree(Eucalyptus spp.) respectively. Higher densities were recorded in Muqdadiyah (200), Balad rooz (193), Kalas (113) and decreased to( 65) adults in Khanakin. Found that the higher percentage for species $E$. integriceps then followed $E$. testudinaria finally the species $E$. maura in all region in Diyala governorate.

Key word :Eurygaster maura,Eurygaster testudinaria ,hibernated ,diagnostic, overwintered *Post of Ph.D. dissertation of the first author

شبلاوي والجوراني 1122-1118:(6)49: 2018- مجلة العلوم الزراعية العراقية انواع حشرة السونه ومناطق تثتيتها في محافظة ديالى /العراق :

$$
\text { رضا صكب الجوراني }
$$$$
\text { كلية الزراعة جامعة بغداد }
$$

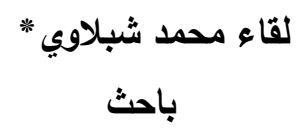

المستخلص

اجريت دراسة في محافظة ديالى/ العرلق خلال فترة تثتية حشرة السونه من كانون الاول 2016الى شباط 2017. شخصت

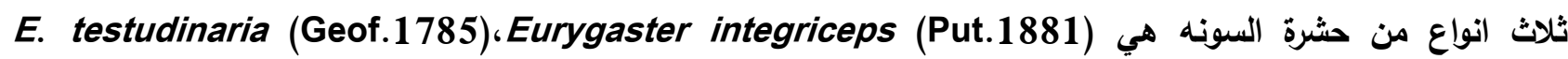
و E.maura(Len.1758،والنوع الاخير يعد تسجيل جديد للعراق. وجدت الانواع الثلاثة مشتيه تحت اورلق الاشجار، الادغال، وتحت قواعد سعف النخيل. اكبر عدد للبالغات المشتية (44,51,56,68)بالغة /م5 تحت ادغال الحلفا (Imperata (Cylindrican Len. والاورلق المتساقطة لأشجار اليوكالبتوز (Eucalyptus. spp)على التوالي أعلى كثافة عددية للبالغات المشتية سجلت في منطقة المقدادية ويلغت(200) بالغة بينما منطقة بلا روز سجلت (193) بالغة ومنطقة الخالص سجلت (113) بالغة وسجل

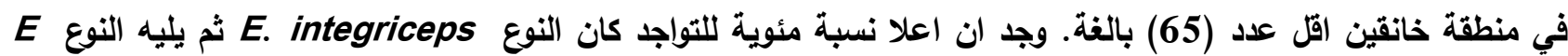
testudinaria الكلمات المفتاحية: Eurygaster testudinaria، Eurygaster maura ، التشخيص، التشتية "جزء من اطروحة دكتوراه للباحث الاول 


\section{INTRODUCTION}

Bread wheat is an important food crop on the world level .The main problem in Iraq in the deficit in the wheat production (13). Wheat infected with many pest both in the field and storage lead to economic losses $(5,2)$. Wheat bug (Euregaster spp.)(Hemiptera: scutelleridae), are the most serious pest of wheat and barley in the wide area of the Near and Middle East West Asia and many of the new independent states of center Asia and Eastern and south Europe and north Africa $(15,16,18)$. The genus Eurygaster spp (Laporte,1833) includes 19 species ,four of them are grain pastes. E. integriceps (Puton), E.maura (Linnaeus, 1758) , E. testudinaria (Geoffroy,1785) and E.austriaca (Schrank ,1776) $(11,12)$. These species caused yield losses about $20-30 \%$ for barley and 50-90\% for wheat (9). Yield loss is a result of pest feeding by sucking nutrients from leaves ,stems ,and grains which inject enzymes on it that degraded gluten proteins, and then reduced the quality of flours made from damaged wheat grains.(7,14).Sunn pest Eurygaster integriceps Puton, was first recorded in north of Iraq in 1920(Ridha,1959) and then spread to most cereal fieled (wheat and barley)in Erbil ,Dohok,Nainawa and Sulaimanya (8). The infestation map of this pest was changes dramatically from 1980-2000, and colonized wheat and barley filed grown in irrigated regions at most central and middle Euphrates governorates such as Salahaldin, Baghdad, Diyala, AL- Anbar and Babil (10).A new sunn pest species Eurygaster testiudinaria (geoffroy)was recorded for the first time at the middle Euphrates region of Iraq on wheat and barley fields $(3,4)$.Several sunn pest outbreak was occurred in the middle Euphrates governorates of Iraq , and many aerial spraying of broad- spectrum insecticides were done by the Ministry of Agriculture (Personal communication and internal reports). This research is an attempt to answer the question that raised by many researcher, How this pest was dispersal and colonized many fields of wheat and barley in Diyala governorate, especially with outbreaks that occurred in many past years ,and the species of the genus Eurygaster and their hibernation sites.
MATERIAL AND METHODS

The study was conducted in Diyala governorate/Iraq during wintering period of the sunn pest from Dece. 2016 to Feb. 2017. The governorate was divided four region according to their importance and production of wheat and barley crop .These regions are :Muqdadiyah , Kalas, Balad- rooz and Khanakin .The fields of wheat and barely were targeted as well as nearby highlands, orchards, house hold and weeds. Sampled areas were scouted. with the assistance of a square meter and randomly selected 5 location the wintered adults was keep in plastic tubs and all information was recorded directly .Many specimen were prepared and sent to Natural History Museum Unive. Of Baghdad and anther to Dr. A.Abdal Fattah for diagnostic purpose.

\section{RESULTS AND DISCUSSION}

Eurygaster species: Three species of sunn pest was diagnostic. These species are Eurygaster integriceps (Puoton, 1881), E. testudinaria (Geoffory, 1785) and E. maura (len.1758).E .maura was new species recorded to Iraq funna .E. integriceps is The most abundance of the three species hibernated in the fields of the four region of Diyala governorate . E. .testudinaria which recorded previously in Najef ,Diwaniya and Karbala (4) and may be dispersal to anther governorates throughout the past year especially with the expanded of area cultivated by wheat and barley as well as introduced a new verities of these crops. E. maura was found with E. integriceps in wheat fields and at higher altitudes in the aestivation and hibernation sites in many region in Iran (19).In general E. maura was dispersal to fields of wheat and barley in Diyala governorate from this Iranian regional. This result confirmed that wheat and barley fields in Diyala governorate was infected with the same species that diagnostic in thes study. The most common sunn pest species have been shown in the dormancy location (Gara mountain) in north of Iraq was E. integriceps, the percentage of its appearance was $79.70 \%$ followed by Dolycoris baccarum L.and the Carpocoris fuscispinus Boh. And Aelia acuminate L. which estimated at $(18.85,1.47$ and 0.98$) \%$ respectively(1). 


\section{Hibernation sites}

The results showed that the three species of genus Eurygaster which diagnostic in Diyala governorate were overwinter as an adults under bushes ,dead leaves, weed ,date palm leaf base (Table1).The heights total number of adults $(68,56,51$ and 44 adults $/ 5 \mathrm{~m} 2)$ was found under Blady grass(Imperata cylindrican L.) ,Bermuda grass(Cyndo dactylon L.),Grape tree(Vitis vinifera L.)and Eucalyptus tree(Eucalyptus spp.)respectively . Yildirim et,al 2007recorded two species E. maura and E.austrica lives from autumn to spring under leaves of oak ,Pinus spp,thymus spp, Acantholiman spp and Astragalus spp. Higher densities were recorded in Muqdadiyah (200), Balad-rooz (193), Kalas (113) and decreased to (65) adults in Khanakin . Because wheat fields in both Muqdadiyah and Balad Rooz are larger than the area of agriculture and surrounded by orchards, This is because the area cultivated in Khanakin with wheat crop is few and far from orchards. Field observation and research data confirmed the hibernation of sunn pest E. integriceps under date plam leaf base, bland weeds and rice hay in Diwaniya and Najaf governorates during winter and early spring (10). Sunn pest E. integriceps in north of Iraq hides under many plants for summer aestivation and winter hibernation and its number in Siffin Mountain ranged fore 284331 adults $/ 10 \mathrm{~m} 2$ with an average 301.6 adult $/ 10 \mathrm{~m} 2$.This variation in sites of hibernation may be explain the tolerant of this species to wide range of temperature or anew biotype that adapted to higher temperature (especially in summer )in the middle of $\operatorname{Iraq}(6)$. The average population of sunn pest were (51.00and 44.46)insect $/ 5 \mathrm{~m}^{2}$ at the end of October and the beginning of November respectively(1). The reason for the existence of these species in the orchards, fields and jungles plant is to protect themselves from the high temperature in the summer(aestivation) and decline in winter (hibernation) and the absence of mountain areas in the province of Diyala, it leads to these areas

Table1:No. of suun adult and locale hibernation

\begin{tabular}{|c|c|c|c|c|c|c|c|}
\hline \multirow[t]{2}{*}{ No. } & \multirow[t]{2}{*}{ Commune name } & \multirow[t]{2}{*}{ Scientific name } & \multicolumn{5}{|c|}{ Number of adult of sunn $/ 5 \mathrm{~m} 2$} \\
\hline & & & 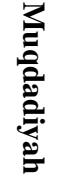 & 정 & 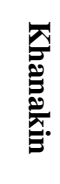 & 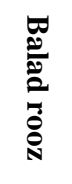 & \\
\hline .1 & Blady grass & Imperata cylindrical $L$ & 21 & 16 & 11 & 20 & 68 \\
\hline .2 & Date palm & Phoenix dactylifera & 18 & 6 & & 9 & 33 \\
\hline .3 & $\begin{array}{l}\text { Pomegranate } \\
\text { tree }\end{array}$ & Punica granatum & 15 & 9 & & 10 & 34 \\
\hline .4 & Grape tree & Vitis vinifera & 16 & 12 & 5 & 18 & 51 \\
\hline .5 & Apple tree & Malusa communis & 4 & 7 & 8 & 10 & 29 \\
\hline .6 & Pear tree & Pyrus communis & 10 & 7 & 5 & 8 & 30 \\
\hline .7 & Apricot tree & Prunus armeniaca & 9 & 4 & 6 & 6 & 25 \\
\hline .8 & Peach tree & Prunus persica & 7 & 5 & 6 & 7 & 25 \\
\hline .9 & Eucalyptus tree & Eucalyptus communas & 16 & 4 & 6 & 18 & 44 \\
\hline .10 & Poplar tree & Populus euphratica & 10 & 3 & & 8 & 21 \\
\hline .11 & Tamaeix tree & Tamarixspp. & 9 & 3 & 5 & 12 & 29 \\
\hline .12 & $\begin{array}{l}\text { Dadonea } \\
\text { shrubbery }\end{array}$ & Dadonea viscosa & 9 & 5 & 3 & 9 & 26 \\
\hline .13 & $\begin{array}{l}\text { Myrtus } \\
\text { shrubbery }\end{array}$ & Myrtus communs & 12 & 8 & & 11 & 31 \\
\hline .14 & Bermuda grass & .Cyndo dactylon $L$ & 12 & 9 & 10 & 25 & 56 \\
\hline .15 & $\begin{array}{l}\text { Weed in groves } \\
\text { citrus }\end{array}$ & Many species & 14 & 7 & & 12 & 33 \\
\hline .16 & $\begin{array}{l}\text { Weed in groves } \\
\text {.Pomegranate }\end{array}$ & Many species & 18 & 8 & & 10 & 36 \\
\hline .17 & Total & & 200 & 113 & 65 & 193 & 571 \\
\hline
\end{tabular}


Percentage of the species in different region

The highest percentage of Eurygaster integriceps was found in Balad rooz, Muqdadiyah, Kalas and Khanakin $(54.9,54.5,79.3) \%$ respectively The $E$.

Tbale 2.Percentage of the three species of sunn pest in different region of Diyala governorate

\begin{tabular}{|c|c|}
\hline Region & \\
\hline & Eurygaster integriceps \\
Balad rooz & $\% 54.9$ \\
Muqdadiyah & $\% 54.5$ \\
Kalas & $\% 79.3$ \\
Kanakin & $\% 89$ \\
\hline
\end{tabular}

\section{REFERENCES}

1. Abdullah,S.I. and L.H.A ALDoske. 2010 .The first survey of the dormancy locations of the sunn pest Eurygaster integriceps Put. in Dohuk province .J.K.A.S.(1)2:1-8

2. Abdullah,L.M and M .Z Raouf. 2005. .Evaluation of infestation degree by hairy grain beetle Trogoderma granarium Eve.)(Colleoptera :Dermestidea) for two wheat varieties during 1-6 months of storage of 2002. Iraqi Journal of Agriculture Sciences (36) $5: 125-130$

3. Abdul- Razak Z . and H. F. Alrubeai 2011. Identification of New Sunn Pest Species, Eurygaster testudinaria Geoffroy with Studies of Its Biology and Ecology at the Middle Euphrates Region of Iraq. pp:13

4. Abdul- Razak Z. and H. F. Alrubeai 2011. Efficency of pest Eurygaster Testudinaria (Geoffroy) Egg Prastaoids in Najaf Government. Egyptian Journal of Biological Pest Control.21(2): 361-368

5. AL-Chalabi,F.T. and H.S.AL-Agidi,. 2010. Weed competition and its impact on growth characters of some wheat cultivars. Iraqi Journal of Agricultur of Sciences (41) 2:53-63 6. Amin,A.B., A.J. Mohammed and H.S ALAssadi. 2007 .Population Density of Sunn Pest During Hibernation and Aestivation in Northern Iraq .Parkar,B.M.,Margaret S.,Mustapha EL B.H.andSafaa G.K.(Eds)sunn pest management:ADecade of progress 19942004.pp: 448

7. Critchely B.R. 1998 Literature review of sunn pest Eurygaster integriceps Puton. (Heteroptera ; Scutelleridae).Crop Prot. (17): 271-287

8. EL-Haidary H., A.N. Nouman and M. K. Abad 1960. Sunn Pest Technical Buiitetin. testudinaria was the same in the same areas $(40.8,45.5,20.7,11) \%$ respectively, While the E. maura was only found in the Balad Rose region with $13.3 \%$ present

\begin{tabular}{|cc|}
\hline Eurygaster testudinaria & Eurygaster maura \\
$\%$ 40.8 & $\% 13.3$ \\
$\% 45.5$ & 0 \\
$\% 20.7$ & 0 \\
$\% 11$ & 0 \\
\hline
\end{tabular}

No.6 Directory of Research and General Agricultural Projects Iraq.(in Arabic).pp:16

9. Gul, A., A .CAUMA and D.Mithat 2006. Sunn pest control policies and effect of sunn pest damge on wheat quality and price in Turkey. Quality and Quantity( 40): 469-480.

10. Hama, N.N., Z.A. Stephan, M.A. Ali and M.L. Aboud. 2007. Sunn Pest Status in Iraq. Parkar,B.M.,Margaret S.,Mustapha EL B.H.andSafaa G.K.(Eds)sunn pest management:ADecade of progress 19942004.pp:448.

11. Javahery, M. 1996.Sunn Pest of Wheat and Barley in Islamic Republic of Iran (Chemical and Cultural Methods of Control .Sunn Pest and Their Control in the New Est. .edited by R.H.Miller and J.G.Morse plant production ,(FAO)Rom(1996) pp:11

12. Javahery, M. 1995. A technical Review of Sunn Pests (Heteroptera Pentatomoidea) with special reference to Eurygaster integriceps Puton. FAO/RNE Publ. Priv. pp:80.

13. Kadam,M.S. and A.S. AL-Hani, 2011.An estimation of supply response for bread wheat in Iraq for the Period 1991-2002. Iraqi Journal of Agriculture Sciences.(42)5:74-80

14. Lodos N.1986.Turkey Entomology ii.general applied and funistik. Ege University Faculty of Agriculture Publication Izmir ;no;429, E. U. Mat. Bornova, Izmir. pp: 591

15. Radjabi G.H. 2000. Ecology of Cereals Sunn Pest in Iran .Agricultural Research, Education and Extension Rganization Tehran ,Iran pp:343

16. Reynolds, M. P., J. Pietragalla, and H. J. Braun, 2008 .International Symposium on Wheat Potential: Challenges to International Wheat Breeding, Mexico,CIMMYT.pp:197 
17. Ridha,O. 1959. Sunn Pest .Iraq Agriculture ,Bulletin. Ministry of Agriculture (in Arabic). pp:49-68

18. Sanaey,N. and T.N Mirak,. 2012. Wheat resistance to the adult insect of sunn pest Eurigaster integriceps Put .Americana Journal of Agriculture and Biological Sciences. (7) $1 ; 56-60$
19. Schaefar, C. W. and A. R. Panizzi 2000. Heteroptera of Economic importance .CRC Press.pp:852

20. Yildirim,A.F.,E.Kinaci and M. (Elmali) Uysal. 2007.Sunn Pest Over Wintering Sites Parasitoids and Effects on Cereal Lines and Varieties. Parkar ,B. M. Margaret S.,Mustapha EL B.H.andSafaa G.K.(Eds)sunn pest management:ADecade of progress 19942004.pp:448. 